\title{
Aplikasi Senyawa Aktif Bakteri Endofit Potensial dan Pupuk Terhadap Penyakit Layu Daun, Busuk Buah pada Tanaman Tomat
}

\author{
Ruth Melliawati ${ }^{1}$ dan Joko Purnomo ${ }^{2}$ \\ ${ }_{1}^{1}$ Pusat Penelitian Bioteknologi - LIPI JI. Raya Bogor KM. 46 Cibinong 16911 \\ ruthmell2000@yahoo.com \\ ${ }^{2}$ Balai Penelitian Tanah pada Badan Litbang Pertanian Jl. Tentara Pelajar 12 Bogor \\ Purnomo0204@gmail.com
}

\begin{abstract}
The purpose of this research is to know the influence of bacterial endophyte and potential applications of fertilizer to disease wilted leaves and rotten fruit by bacteria Pseudomonas solanacearum. Two bacterial endophyte selected (HL. 39B. 86 and HL. 39B. 88) is used in this research to applied on tomato plants. The fermentation process is done in two kinds of liquid medium to seek maximum growth pattern. The experiment was conducted in 2 units. The experiments 1 . Test the 10 isolates of bacterial endophyte against attacks of the disease wither on the plant tomatoes and chilies, experiment II. Apply the compound active potential of bacterial wilt disease and rotten fruit on tomato plants. TLC analysis results show that both of these bacteria produce active compounds, by looking at the stain (spot) on TLC. The results showed that bacterial endophyte HL. 39B. 86 and HL. 39B. 88 able to withstand and protect the attack of bacteria wilt disease of $P$. Solanacearum in tomato plants. Granting of fertilizer $N$ and $K$ real increase weight of tomato fruit, but no real increase weight of biomass, plant height, and the width of the canopy tomatoes.
\end{abstract}

Keywords: A compound active microbes potential, Microbes endophite, Tomato plants.

\begin{abstract}
ABSTRAK
Tujuan penelitian ini adalah untuk mengetahui pengaruh aplikasi bakteri endofit potensial dan pupuk terhadap penyakit layu daun dan busuk buah oleh bakteri Pseudomonas solanacearum. Dua bakteri endofit terseleksi (HL.39B.86 dan HL. 39B.88) digunakan dalam penelitian ini untuk diaplikasikan pada tanaman tomat. Proses fermentasi dilakukan dalam 2 macam medium cair untuk mencari pola pertumbuhan yang maksimal. Percobaan dilakukan dalam 2 unit percobaan. Percobaan I.Menguji 10 isolat bakteri endofit terhadap serangan penyakit layu pada tanaman tomat dan cabe, percobaan II.Mengaplikasi senyawa aktif bakteri potensial terhadap penyakit layu dan busuk buah pada tanaman tomat Hasil analisis KLT menunjukkan bahwa kedua bakteri tersebut menghasilkan senyawa aktif, dengan melihat noda (spot) pada kertas KLT. Hasil penelitian menunjukkan bahwa bakteri endofit HL.39B.86 dan HL. 39B.88 mampu menahan dan memproteksi serangan penyakit layu dari bakteri $P$. Solanacearum pada tanaman tomat. Pemberian pupuk $N$ dan $\mathrm{K}$ nyata meningkatkan bobot buah tomat, tetapi tidak nyata meningkatkan bobot biomas, tinggi tanaman, dan lebar kanopi tomat.
\end{abstract}

Kata kunci: Mikroba endofit, Senyawa aktif mikroba potensial,Tanaman tomat.

\section{Pendahuluan}

Indonesia merupakan salah satu negara tropis yang kaya dengan sumber daya hayati, termasuk sumber daya mikrobanya. Sumber daya mikroba dapat dieksplore dari alam termasuk dari dalam jaringan tanaman. Saat ini efektivitas mikroba endofit yang hidup di dalam jaringan tanaman terus digali potensinya untuk keperluan industri maupun pertanian. 
Beberapa penelitian menunjukkan kemampuan kapang endofit dapat menghasilkan berbagai senyawa, seperti enzim (Teske dan Trentini, 1995; Bezerra et al., 2012, zat-zat antitumor (Chandra, 2012), senyawa antimikroba (Souza et al., 2004; Siqueira et al., 2011; Pinheiro et al., 2013), dan hormon pertumbuhan tanaman (Hwang et al., 2011). Sementara itu penggunaan kapang endofit di berbagai proses industri dipelajari lebih lanjut sehingga ditemukan senyawa baru potensial untuk industri dan farmasi (Meng et al., 2011; Wang dan Dai, 2011). Studi tentang kapang endofit memberikan kontribusi pengetahuan tentang keragaman dalam kelompok endofit dan juga spesies baru, yang menghasilkan metabolit ekstraseluler (Siqueira et al., 2008, 2011). Telah dipelajari pula tanaman obat dilihat dari sudut pandang potensi interaksi endofit yang menunjukkan banyak manfaat, seperti produksi antibiotik, metabolit sekunder farmakologis, vitalitas biomarker dan pengendalian agen hayati terhadap hama dan penyakit (Sun et al., 2008; Hilarino et al., 2011; Bagchi dan Banerjee, 2013; Pinheiro et al., 2013).

Wang et al. 2012 melaporkan bahwa endofit Phoma sp. yang diiisolasi dari tanaman obat Arisaema erubescens dilaporkan menjadi sumber yang menjanjikan senyawa antimikroba. Dilaporkan pula bahwa endofit Phoma sp. menghasilkan senyawa turunan $\alpha$-tetralone baru (3S) - 3,6,7 - trihydroxy- $\alpha$-tetralone cercosporamide, $\beta$-sitosterol dan trichodermin. Senyawa ini terseleksi sebagai antibakteri dan antijamur melawan patogen jamur Fusarium oxysporum, Rhizoctonia solani, Colletotrichum gloeosporioides dan Magnaporthe oryzae, juga melawan dua bakteri patogen tanaman lainnya yaitu Xanthomonas campestris dan Xanthomonas oryzae .

Selain mikroba yang bermanfaat, banyak juga mikroba yang menjadi penyakit bagi tanaman pertanian. Misalnya penyakit layu daun oleh bakteri/kapang, busuk akar/ batang/buah, hawar daun, antraknosa, rebah kecambah dan sebagainya. Penggunaan mikrobisida kimiawi efektif untuk membasmi mikroba patogen, tetapi sebaiknya dibatasi karena berdampak negatif, baik mencemari lingkungan maupun meracuni hewan dan manusia (Widarto 2008). Penggunaan mikrobisida kimiawi pada pertanian organik sangat dihindari karena tidak baik untuk kesehatan. Salah satu cara alternatif untuk mengendalian mikroba patogen yaitu dilakukan secara hayati dengan menggunakan mikroba antagonis.

Clay (1988) melaporkan bahwa mikroba yang berasal dari rumput telah diaplikasikan untuk keperluan industri dan pertanian. Diketahui bahwa kapang endofit mempunyai hubungan mutualistis dengan tanaman inangnya yaitu memproteksi melawan herbivor, serangan serangga atau jaringan yang patogen (Siegel et al., 1985, Clay, 1986, Yang et al., 1994). Hubungan yang saling menguntungkan antara mikroba dengan tanaman adalah karena kontribusi bahan kimia yang dihasilkan oleh mikroba, antara lain 
memiliki berbagai senyawa bioaktif yang berguna bagi tanaman (Strobel et al. 1996., Cacabuono and Pomilio, 1997, Rizzo et al., 1997, Fabry et al., 1998).

Bakteri dan kapang endofit yang berasal dari tanaman di Taman Nasional Gunung Halimun mampu menghasilkan senyawa aktif antibakteri dan antikapang pathogen (Melliawati et al., 2006, 2007, Melliawati dan Wulandari, 2008, Melliawati dan Harni, 2009). Yusniawati (2009) melaporkan bahwa Streptomyces isolat lokal mampu menghambat serangan S. rolfsii pada tanaman tomat, dan cabai (Papuangan, 2009), $R$. solanacearum pada tanaman cabai (Muthahanas, 2004) dan Xanthomonas axonopodis pada tanaman kedelai (Ifdal, 2003 dan Andri, 2004).

Sutakaria (1975) mengemukakan bahwa mikroba yang bersifat patogen dan menyerang tanaman pertanian diantaranya adalah Fusarium conglutinans menyerang tanaman kubis, $F$. oxysporum, $F$ cubence menyerang tanaman pisang. Roth dan Riker (1943) melaporkan bahwa Synchytrium endoboiticum banyak merugikan tanaman kentang dan Pythium sp menyerang bibit pinus. Schneider (1954) dalam Hadi et al. (1976) melaporkan bahwa beberapa patogen, hidup dalam tanah seperti misalnya Rhizoctonia solani, Thielaviopsis basicola, Verticillium alboatrum dsb. Demikian pula Van Der Goat dan Muller, 1931/1932 dalam Semangun, 1971 melaporkan bahwa bakteri seperti Xanthomonas phaseoli, $X$. solanacearum, Scleerotium rolfsii dapat berkembang dalam cuaca yang lembab sementara $P$. glycines dapat menyerang tanaman kedelai yang menyebabkan bercak bercak nekrotis pada daunnya (Sutakaria, 1964).

Tomat merupakan salah satu komoditas hortikultura yang penting dan bernilai ekonomi tinggi (Solanum lycopersicum), namun produksinya masih rendah (Wijayani dan Widodo, 2005). Pada tahun 2015 rata-rata produksi tomat di Indonesia mencapai 877.728 ton/tahun dengan luas panen 54.543 ha dan produktivitas 16,09 ton/ha (BPS. 2016. Produksi ini masih rendah, bila dibandingkan dengan produksi tomat di negara lain. Salah satu penyebab rendahnya produktivitas tanaman tomat di Indonesia adalah serangan mikroba patogen. Menurut Semangun (1994), beberapa mikroba patogen yang menyerang tanaman tomat antara lain: Fusarium oxysporum (layu Fusarium), Phytophthora infestans (hawar daun), Sclerotium rolfsii dan Rhizoctonia solani (rebah kecambah), Colletotrichum capsici (antraknosa) dan Rasltonia solanacearum (layu bakteri). Kehilangan hasil produksi tomat yang disebabkan oleh penyakit layu Fusarium diperkirakan mencapai 10-40\%, hawar daun 10-100\% (Suryaningsih et al., 1999).

Kegagalan panen sering dialami petani akibat serangan Pseudomonas dan xanthomonas. Bakteri Pseudomonas menyerang tanaman kelompok solanaceae, juga tembakau dan durian sedangkan Xanthomonas menyerang tanaman jeruk, tomat juga pisang. Pengendalian penyakit tanaman sudah dilakukan baik secara kimiawi maupun 
alami namun sejauh ini belum dapat mengendalikan secara tuntas, sehingga dalam kurun waktu tertentu serangan penyakit terhadap tanaman terulang kembali.

Tujuan penelitian ini adalah mengetahui pengaruh mengaplikasikan senyawa aktif bakteri endofit potensial dan pupuk pada tanaman tomat dan menguji kemampuan senyawa aktif bakteri endofit tersebut dalam memproteksi tanaman terhadap bakteri pathogen.

\section{Bahan dan Cara Kerja}

\section{Seleksi media pertumbuhan bakteri endofit}

Sebanyak 2 (dua) isolat mikroba endofit potensial yang terpilih ditumbuhkan pada 2 macam medium cair (media I: Nutrient broth dan media II: meat extract $5 \mathrm{~g} / \mathrm{l}$, pepton 10 $\mathrm{g} / \mathrm{l}$ dan $\mathrm{NaCl} 5 \mathrm{~g} / \mathrm{l}$ ). Kedua media disterilisasi, diinokulasi dan selanjutnya diinkubasikan pada sheaker incubator pada suhu ruang pada 150 rpm selama 8 hari. Pengambilan sampel dilakukan setiap 24 jam untuk pengukuran $\mathrm{OD}, \mathrm{pH}$ dan untuk mengetahui pola pertumbuhannya.

\section{Produksi senyawa aktif dan ekstraksi}

Mikroba endofit potensial ditumbuhkan pada medium cair terpilih menggunakan Erlenmeyer. Pemanenan kultur dilakukan pada waktu kondisi optimal untuk menghasilkan senyawa aktif yang maksimal. Ekstraksi dilakukan terhadap sample sebanyak 3 kali dengan menambahkan chloroform (1:1), ekstrak dievaporasi selama kurang lebih 15 menit pada suhu $40^{\circ} \mathrm{C}$. Selanjutnya dilakukan KLT dengan fase gerak chloroform dan methanol (5:1) untuk mengkonfirmasi adanya bioaktif yang dihasilkan oleh mikroba potensial.

\section{Perbanyakan kultur bakteri endofit terpilih}

Bakteri endofit yang akan diaplikasikan, ditumbuhkan pada medium cair terpilih dalam Erlenmeyer dan diinkubasikan selama waktu tertentu (pertumbuhan mikroba maksimal). Penghitungan jumlah sel bakteri dilakukan untuk mengetahui populasi sel bakteri sebelum digunakan.

\section{Aplikasi kultur pada tanaman}

Aplikasi kultur bakteri endofit terhadap tanaman tomat dilakukan di Balai Penelitian Tanah, Sindang Barang, Laladon, Bogor, dengan cara: benih tomat direndam selama 1-2 jam dalam suspensi mikroba endofit potensial, kemudian ditanam/disemaikan pada tanah steril dalam pot persemaian. Bibit tomat (kurang lebih berumur 2 minggu) dipindahkan/ditanam pada tanah steril dalam polibag yang sebelumnya telah diberi pupuk sesuai perlakuan (Tabel 1 dan Tabel 2). Tanah yang digunakan untuk percobaan I adalah setara dengan $4 \mathrm{~kg}$ kering oven/pot, sedang pada percobaan II adalah 7,5 kg/pot. 
Contoh tanah Andisol diambil dari Cisarua, Bogor. Karakteristik tanah adalah rendah kalium dan $\mathrm{pH}$ antara 5-6. Kedua unit percobaan tersebut menggunakan rancangan acak lengkap.

Pada saat benih ditanam dalam polibag, suspensi mikroba endofit disiramkan pada tanaman dan disekitar tanaman tersebut sebanyak $10 \mathrm{ml} /$ tanaman. Pemupukan diberikan kembali setelah tanaman berumur 1 bulan. Tanaman selanjutnya siap diberikan infektor / penyakit dengan kepekatan atau konsentrasi $10^{8} \mathrm{sel} / \mathrm{ml}(10 \mathrm{ml} / \mathrm{tanaman})$. Pemberian infektor dengan cara disiramkan ke tanaman dan tanah disekitarnya. Air penyiraman dilakukan 2 kali/hari atau berdasarkan kebutuhan air untuk menjaga kestabilan tanah agar tidak kekeringan.

Tabel 1. Pengaruh bakteri endofit dan pemupukan NPK pada tanaman tomat terhadap ketahanan bakteri infektor

\begin{tabular}{l|l|l|l|l}
\hline No. & Kode & \multicolumn{1}{c|}{ Bakteri Endofit } & \multicolumn{1}{c}{ Infektor } & Pupuk \\
\hline 1 & Kontrol & - & & - \\
2 & A-P-1 & HL.39B.86 & Pseudomonas solanacearum (P) & N1P1K1 \\
3 & A-C-1 & HL.39B.86 & Colletrotricum glocossporoides (C) & N1P1K1 \\
4 & A-PC-1 & HL.39B.86 & P + C & N1P1K1 \\
5 & A-P-2 & HL.39B.86 & Pseudomonas solanacearum (P) & N2P2K2 \\
6 & A-C-2 & HL.39B.86 & Colletrotricum glocossporoides (C) & N2P2K2 \\
7 & A-PC-2 & HL.39B.86 & P + C & N2P2K2 \\
8 & B-P-1 & HL.39B.88 & Pseudomonas solanacearum (P) & N1P1K1 \\
9 & B-C-1 & HL.39B.88 & Colletrotricum glocossporoides (C) & N1P1K1 \\
10 & B-PC-1 & HL.39B.88 & P + C & N1P1K1 \\
11 & B-P-2 & HL.39B.88 & Pseudomonas solanacearum (P) & N2P2K2 \\
12 & B-C-2 & HL.39B.88 & Colletrotricum glocossporoides (C) & N2P2K2 \\
13 & B-PC-2 & HL.39B.88 & P + C & N2P2K2 \\
\hline
\end{tabular}

Keterangan : $\mathrm{A}=$ Bakteri HL.39 B.86 $\quad \mathrm{B}=$ Bakteri HL.39B.88

Tabel 2. Dosis pemupukan tanaman tomat dan aplikasi isolat bakteri endofit HL.39B.86

\begin{tabular}{|c|c|c|c|c|c|c|c|c|c|c|c|c|}
\hline \multirow[t]{2}{*}{ No } & \multirow[t]{2}{*}{ Perlakuan } & \multicolumn{4}{|c|}{$\begin{array}{l}\text { Dosis Pupuk } \\
\text { (kg/ha) }\end{array}$} & \multirow[t]{2}{*}{$\begin{array}{c}\text { Pukan } \\
\text { (t/ha) }\end{array}$} & \multirow[t]{2}{*}{$\begin{array}{l}\text { Bakteri } \\
\text { infektor }\end{array}$} & \multicolumn{5}{|c|}{$\begin{array}{c}\text { Dosis pupuk (g/pot), 7,5 kg } \\
\text { tanah/pot }\end{array}$} \\
\hline & & Urea & ZA & SP-36 & $\mathrm{KCl}$ & & & Urea & ZA & SP-36 & $\mathrm{KCl}$ & Pukan \\
\hline 1 & N0K2B1 & 0 & 0 & 250 & 160 & 5 & PS, CG & 0 & 0 & 0.94 & 0.6 & 375 \\
\hline 2 & $\mathrm{~N} 1 \mathrm{~K} 2 \mathrm{~B} 1(67.5 \mathrm{~N})$ & 0 & 337.5 & 250 & 160 & 5 & PS, CG & 0 & 1.27 & 0.94 & 0.6 & 375 \\
\hline 3 & $\mathrm{~N} 1 \mathrm{~K} 2 \mathrm{~B} 1(135 \mathrm{~N})$ & 150 & 337.5 & 250 & 160 & 5 & PS, CG & 0.56 & 1.27 & 0.94 & 0.6 & 375 \\
\hline 4 & N3K2B1 $(202.5 \mathrm{~N})$ & 300 & 337.5 & 250 & 160 & 5 & PS, CG & 1.13 & 1.27 & 0.94 & 0.6 & 375 \\
\hline 5 & N2K0B1 $(135 \mathrm{~N})$ & 150 & 337.5 & 250 & 0 & 5 & PS, CG & 0.56 & 1.27 & 0.94 & 0 & 375 \\
\hline 6 & N2K1B1 $(135 \mathrm{~N})$ & 150 & 337.5 & 250 & 80 & 5 & PS, CG & 0.56 & 1.27 & 0.94 & 0.3 & 375 \\
\hline 7 & N2K3B1 (135 N) & 150 & 337.5 & 250 & 240 & 5 & PS, CG & 0.56 & 1.27 & 0.94 & 0.9 & 375 \\
\hline 8 & N2K2B2 $(135 \mathrm{~N})$ & 150 & 337.5 & 250 & 160 & 10 & PS, CG & 0.56 & 1.27 & 0.94 & 0.6 & 375 \\
\hline 9 & N2K2S1 (135 N) & 150 & 337.5 & 250 & 160 & 0 & PS, CG & 0.56 & 1.27 & 0.94 & 0.6 & 375 \\
\hline 10 & N2K2S2 (135 N) & 0 & 675 & 250 & 160 & 0 & PS, CG & 0 & 2.53 & 0.94 & 0.6 & 375 \\
\hline 11 & N2K2 (135 N) & 150 & 337.5 & 250 & 160 & 0 & PS, CG & 0.56 & 1.27 & 0.94 & 0.6 & 375 \\
\hline 12 & $\mathrm{~N} 2 \mathrm{~K} 2 \mathrm{~B} 1(135 \mathrm{~N})$ & 150 & 337.5 & 250 & 160 & 5 & PS, CG & 0.56 & 1.27 & 0.94 & 0.6 & 375 \\
\hline 13 & NoKoBo/Kontrol & 0 & 0 & 0 & 0 & 0 & PS, CG & 0 & 0 & 0 & 0 & 0 \\
\hline
\end{tabular}

\section{Hasil dan pembahasan}

\section{Bakteri endofit potensial}

Melihat data yang dilaporkan Melliawati et al. (2006), sebagian hasil dari seleksi bakteri endofitik terhadap mikroba (bakteri dan kapang) patogen, diperlihatkan pada Tabel 3. Dari Tabel 3 diketahui bahwa 25 isolat bakteri endofitik menunjukkan reaksi positif (antibakteri) terhadap bakteri Xanthomonas campestris, 28 isolat positif antibakteri 
Pseudomonas solanacearum. Sebanyak 14 isolat antibakteri Colletotrichum glocosporoides dan 7 isolat anti terhadap kapang Fusarium Oxysporum cubense. Dilaporkan pula bahwa tidak hanya bakteri endofit saja yang mempunyai kemampuan menghasilkan senyawa aktif anti mikroba pathogen tetapi kapang endofit juga dapat menghasilkan senyawa aktif anti mikroba pathogen bahkan dari 1 isolate kapang mampu menghasilkan 1-3 senyawa aktif anti mikroba pathogen (Melliawati et al., 2007, Melliawati dan Wulandari, 2008, Melliawati dan Harni. 2009).

\begin{tabular}{|c|c|c|c|c|c|}
\hline \multirow[t]{2}{*}{ No. } & \multirow[t]{2}{*}{ Kode Isolat Bakteri } & \multicolumn{4}{|c|}{ Hasil pengujian terhadap mikroba patogen } \\
\hline & & $\begin{array}{c}\text { Xanthomonas } \\
\text { campestris }\end{array}$ & $\begin{array}{l}\text { Pseudomonas } \\
\text { solanacearum }\end{array}$ & $\begin{array}{l}\text { Colletotrichum } \\
\text { glocosporoides }\end{array}$ & $\begin{array}{c}\text { Fusarium } \\
\text { oxysporum } \\
\text { cubense }\end{array}$ \\
\hline 1 & HL.3 B. 19 & + & + & - & - \\
\hline 2 & HL.10B.14 & - & - & + & + \\
\hline 3 & HL.11B.16 & + & + & + & - \\
\hline 4 & HL. 12 B. 19 & + & + & + & - \\
\hline 5 & HL.20 B.38 & + & + & + & - \\
\hline 6 & HL.32B.72 & - & - & + & + \\
\hline 7 & HL.39 B.86 & - & + & + & - \\
\hline 8 & HL.39 B.88 & + & + & ++ & - \\
\hline 9 & HL.42B.95 & - & - & + & + \\
\hline 10 & HL.50B.106 & - & - & + & + \\
\hline
\end{tabular}

Berdasarkan data dari Tabel 3, maka terpilih 2 isolate untuk digunakan dalam penelitian ini yaitu HL.39B.86 dan HL.39B.88. Kedua isolate bakteri ini menghasilkan senyawa antibakteri Pseudomonas solanacearum dan Colletotrichum glocosporoides. Khusus untuk isolate bakteri HL.39 B.88 mampu menghasilkan senyawa aktif antibakteri Xanthomonas campestris. Dalam mempersiapkan kultur/senyawa aktif anti bakteri tersebut, maka perlu dipelajari pola pertumbuhan dari kedua isolate bakteri tersebut.

Pola pertumbuhan bakteri dapat dilihat pada Gambar 1 dan 3 dan perubahan $\mathrm{pH}$ selama proses fermentasi pada Gambar 2 dan 4. Pertumbuhan sel bakteri HL.39B.86 tertinggi dicapai dalam medium II dalam waktu 2 hari $\left(1,81 \times 10^{10} \mathrm{cfu} / \mathrm{ml}\right)$, sementara dalam medium I diperoleh $1,56 \times 10^{10} \mathrm{cfu} / \mathrm{ml}$ dalam waktu 5 hari inkubasi. Perubahan $\mathrm{pH}$ terjadi, baik pada medium I maupun medium II, pH awal 6,76 kemudian naik tajam masing masing menjadi 8,21 dan 7,95 selama fermentasi berlangsung (Gambar 2) dan untuk selanjutnya pH terjadi fluktuasi namun tidak terlalu nyata. Untuk isolat HL.39B.88 dalam medium I jumlah sel dicapai $3,67 \times 10^{9} \mathrm{cfu} / \mathrm{ml}$ (4 hari inkubasi) dan pada medium II jumlah sel tertinggi $5,3 \times 10^{8} \mathrm{cfu} / \mathrm{ml}$ dalam masa inkubasi 5 hari (Gambar 3), $\mathrm{pH}$ meningkat pada awal fermentasi menjadi 8,07 pada kedua medium tetapi kemudian pada hari kedua untuk medium I naik menjadi 8,8 sedang medium II menjadi 8,39 dan selanjutnya $\mathrm{pH}$ mengalami fluktuasi seperti terlihat pada Gambar 4. Terjadinya fluktuasi 
pada $\mathrm{pH}$ medium kemungkinan disebabkan terbentuknya senyawa sekunder selama proses fermentasi berlangsung sehingga menyebabkan perubahan $\mathrm{pH}$.

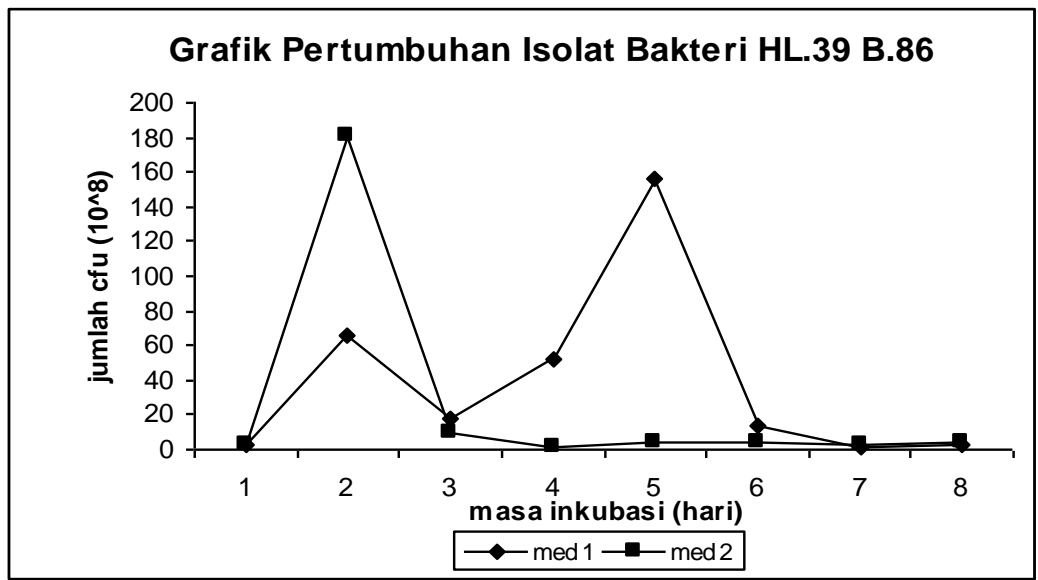

Gambar 1. Pola pertumbuhan isolat bakteri HL.39B.86 pada 2 macam medium selama fermentasi.

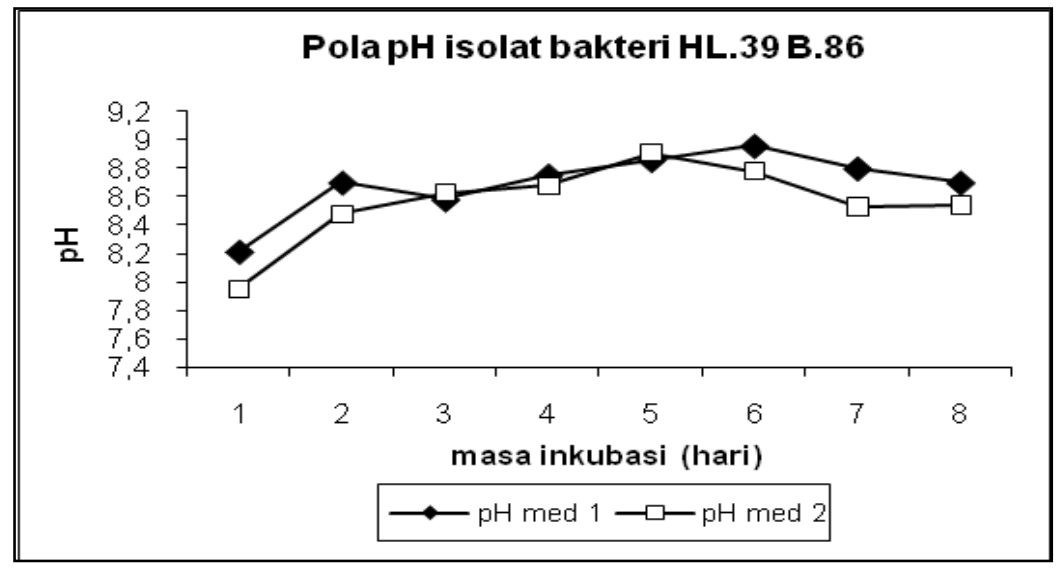

Gambar 2. Pola perubahan pH oleh isolat HL. 39B.86 pada 2 macam medium selama fermentasi.

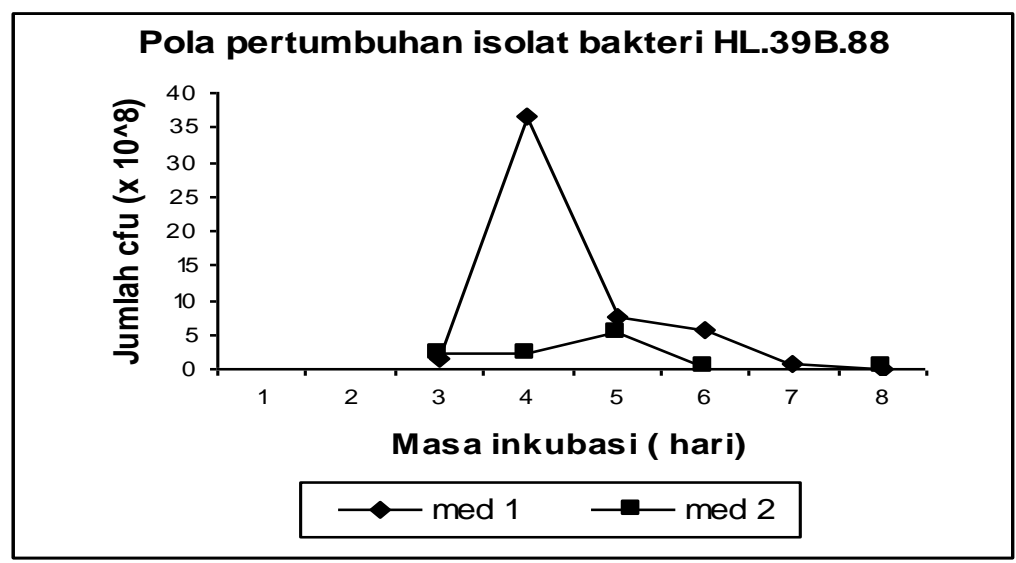

Gambar 3. Pola pertumbuhan isolate bakteri HL.39B.88 selama Fermentasi. 


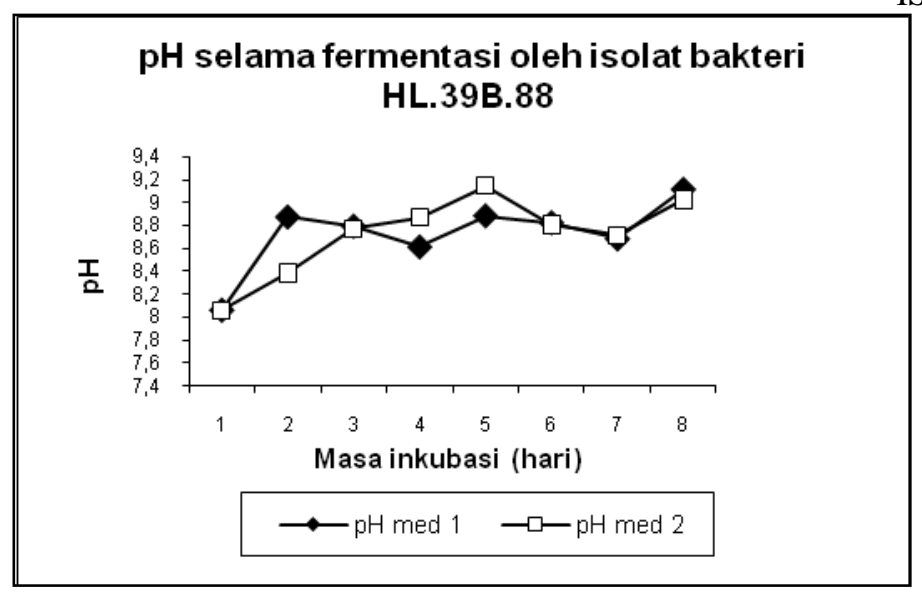

Gambar 4. Pola perubahan $\mathrm{pH}$ selama fermentasi oleh isolat bakteri HL.39B.88.

\section{Ekstraksi dan analisis KLT}

Hasil fermentasi dari kedua isolat tersebut diekstraksi untuk mendapatkan senyawa aktif antibakteri. Ekstrak diuji menggunakan KLT untuk membuktikan adanya senyawa aktif yang dihasilkan oleh kedua isolat bakteri tersebut. Hasil analisis KLT dari bakteri endofit HL.39B.86 dan HL.39B.88 memperlihatkan banyak spot (noda), hal ini menunjukkan bahwa dalam ekstrak masih banyak senyawa lain sehingga perlu dimurnikan (Gambar 5).

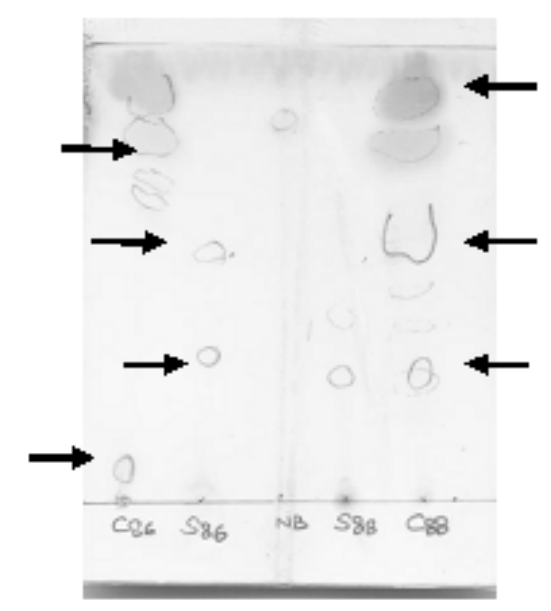

Gambar 5. Hasil KLT terhadap ekstrak bakteri HL.39B.86 dan HL.39B.88 


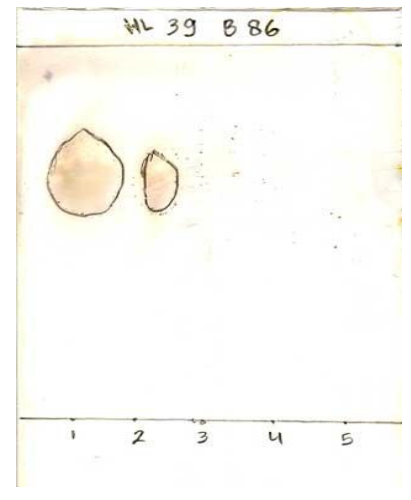

A

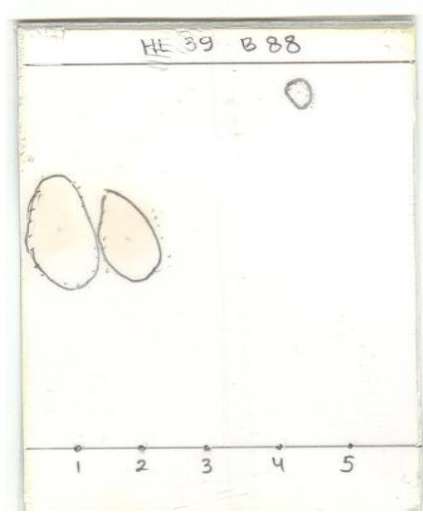

B

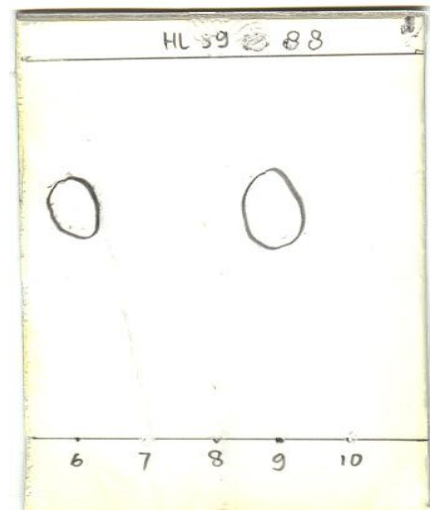

C

Gambar 6. Hasil analisis KLT dari ekstrak bakteri endofit yang sudah melalui pemurnian. Sampel ekstrak HL.39B.86 (A), HL.39B.88 (B dan C)

Gambar 6. memperlihatkan hasil analisis KLT dari ekstrak yang telah melalui pemurnian Gambar 6 A, terlihat 2 spot yang berbeda yaitu pada fraksi 1 menunjukan warna ungu dan fraksi 2 warna merah muda kekuningan dengan $\mathrm{Rf}$ masing masing 0,65 dan 0,61. Sementara pada ekstrak bakteri HL.39B.88 terlihat ada 5 spot yaitu 3 spot pada fraksi 1, 2 dan 4 dengan warna masing masing ungu,ungu dan kuning dengan $\mathrm{Rf}$ masing masing 0,57., 0,54., 0,9 (Gambar 6 B) dan 2 spot pada fraksi 6 dan 9 dengan menunjukan warna masing masing merah muda dgn $\mathrm{Rf}$ 0,6 dan 0,62. (Gambar 6.C) Warna dari spot terlihat jelas setelah melalui penyemprotan dengan $\mathrm{Ce}\left(\mathrm{SO}_{4}\right)_{2}$. Hasil KLT memperlihatkan bahwa dalam ekstrak hasil fermentasi kedua bakteri endofit terdapat senyawa aktif yang bisa menghambat pertumbuhan bakteri athogen. Oleh karena itu untuk pembuktiannya dilakukan uji applikasi ke tanaman. Aplikasi dilakukan terhadap tanaman tomat dengan menggunakan isolate HL.39B.86.

\section{Aplikasi kultur bakteri ke tanaman tomat}

Aplikasi kultur mikroba endofit HL.39B.86 dilakukan terhadap tanaman tomat. Pemberian bakteri sebagai infektor adalah Pseudomonas solanacearum dilakukan pada tanaman umur 4 minggu. Tiga minggu setelah pemberian pathogen terlihat ada satu tanaman yang sebagian daunnya layu (Gambar 7 A) dan pada tanaman lain beberapa buahnya busuk (Gambar 7 B). Sementara buah tomat yang lainnya tetap segar seperti terlihat pada Gambar 7 C. Pada Gambar 7 D diperlihatkan buah tomat siap dipanen pada umur 12 minggu.

Kelihatannya pemberikan bakteri endofit melalui perendaman biji sebelum disemai dan penyiraman pada tanaman tomat sewaktu ditanam pada polybag, cukup dapat mempertahankan serangan Pseudomonas penyebab layu daun. Kelayuan daun pada tanaman tomat hanya terjadi pada satu polybag saja dan serangan infector (Pseudomonas solanacearum) dapat diatasi dengan adanya bakteri endofit yang diberikan, sehingga tanaman tomat masih dapat berbuah dan dapat dipanen. 


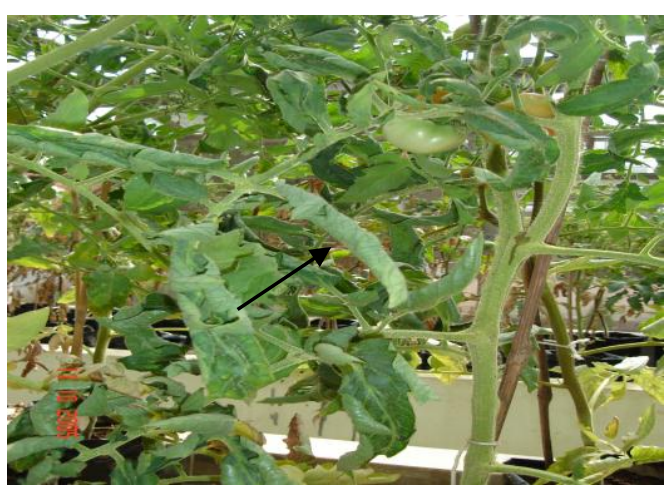

$\mathbf{A}$

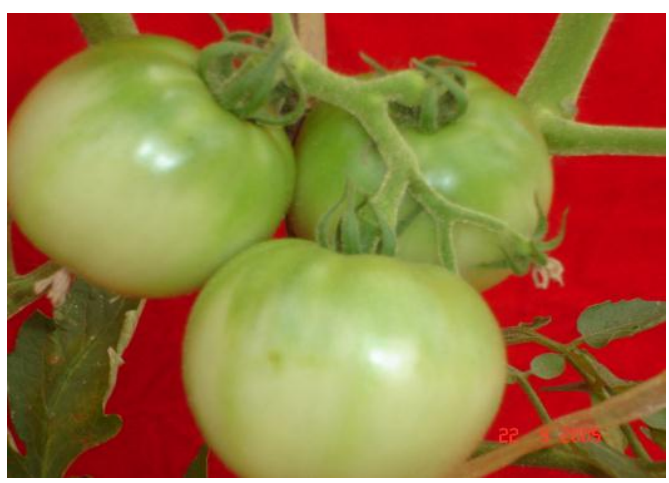

C

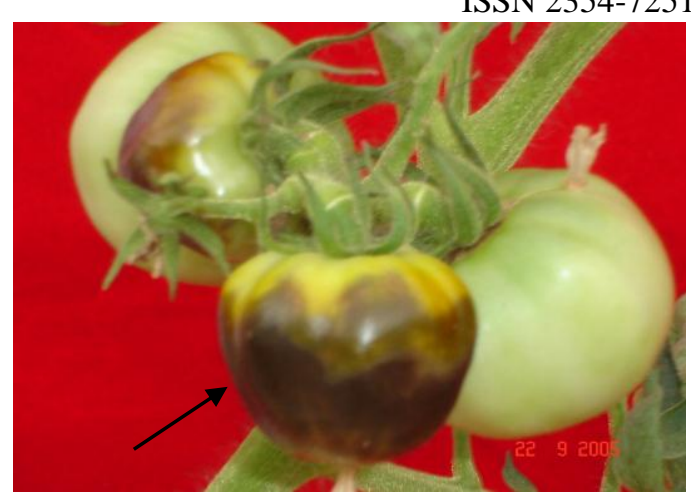

B

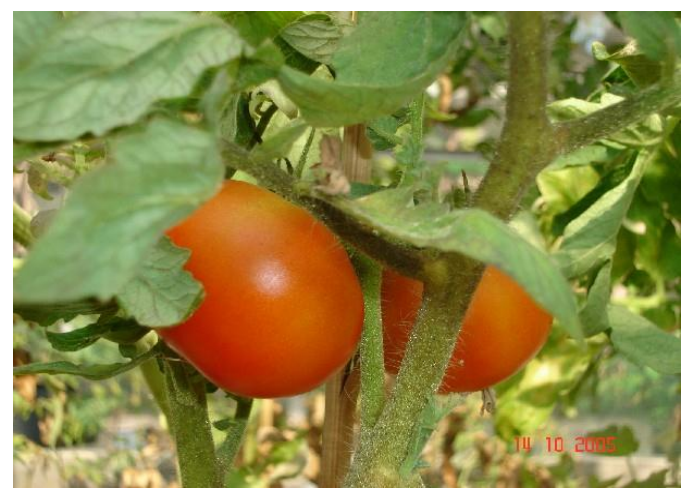

D

Keterangan:

A. Tanaman tomat umur 12 minggu yang terserang virus (daunnya menggulung dan kaku)

B. Buah tomat yang terserang penyakit busuk buah

C. Buah tomat umur 9 minggu yang bebas dari penyakit

D. Tanaman tomat umur 12 minggu yang sudah siap dipanen

Gambar 7. Tanaman tomat pada percobaan II di dalam rumah kaca

\section{Pengaruh Pemberian Pupuk}

Pengaruh pupuk NPKS tidak berpengaruh nyata terhadap tinggi tanaman dan lebar kanopi tomat umur 2, 4, 6, 8 minggu setelah tanam (MST) (Tabel 4 dan 5). Buah Tomat selama penelitian dilakukan panen sebanyak 15 kali panen, kumulatif hasil panen disajikan dalam Tabel 6.

Tabel 4. Pengaruh pemberian pupuk N, K dan bakteri endofit HL.39B.86 terhadap tinggi tanaman tomat

\begin{tabular}{llrrrr}
\hline No & Perlakuan & \multicolumn{5}{c}{ Tinggi Tanaman (cm) } \\
\hline & & $2 \mathrm{MST}$ & $4 \mathrm{MST}$ & $6 \mathrm{MST}$ & $8 \mathrm{MST}$ \\
1 & N0K2B1 & $50.3 \mathrm{~h}$ & $85.7 \mathrm{a}-\mathrm{d}$ & $82.7 \mathrm{~b}$ & $95.7 \mathrm{a}-\mathrm{d}$ \\
2 & N1K2B1 & $45.0 \mathrm{i}$ & $87.3 \mathrm{abc}$ & $115.0 \mathrm{ab}$ & $118.0 \mathrm{a}-\mathrm{d}$ \\
3 & N2K2B1 & $43.3 \mathrm{j}$ & $72.3 \mathrm{e}$ & $90.7 \mathrm{~b}$ & $90.7 \mathrm{~cd}$ \\
4 & N3K2B1 & $53.6 \mathrm{~g}$ & $93.3 \mathrm{~d}$ & $82.3 \mathrm{~b}$ & $87.7 \mathrm{ad}$ \\
5 & N2K0B1 & $53.9 \mathrm{f}$ & $76.0 \mathrm{cde}$ & $109.3 \mathrm{cb}$ & $124.0 \mathrm{abc}$ \\
6 & N2K1B1 & $60.2 \mathrm{a}$ & $88.7 \mathrm{ab}$ & $110.3 \mathrm{ab}$ & $102.3 \mathrm{~d}$ \\
7 & N2K3B1 & $59.5 \mathrm{~b}$ & $87.5 \mathrm{abc}$ & $119.0 \mathrm{ab}$ & $106.0 \mathrm{a}-\mathrm{d}$ \\
8 & N2K2B2 & $56.2 \mathrm{~d}$ & $81.0 \mathrm{~b}-\mathrm{e}$ & $117.3 \mathrm{ab}$ & $115.0 \mathrm{a}-\mathrm{d}$ \\
9 & N2K2S1 & $58.9 \mathrm{c}$ & $73.7 \mathrm{de}$ & $90.3 \mathrm{a}$ & $102.3 \mathrm{a}-\mathrm{d}$ \\
10 & N2K2S2 & $55.4 \mathrm{e}$ & $77.3 \mathrm{~b}-\mathrm{e}$ & $109.3 \mathrm{ab}$ & $127.0 \mathrm{ab}$ \\
11 & N2K2 & $44.8 \mathrm{i}$ & $73.0 \mathrm{e}$ & $110.0 \mathrm{ab}$ & $134.0 \mathrm{a}$ \\
12 & N2K2B1 & $43.4 \mathrm{j}$ & $83.7 \mathrm{a}-\mathrm{e}$ & $118.7 \mathrm{ab}$ & $140.0 \mathrm{a}$ \\
13 & Kontrol & $53.8 \mathrm{fg}$ & $75.0 \mathrm{de}$ & $116.0 \mathrm{ab}$ & $127.7 \mathrm{ab}$ \\
\hline
\end{tabular}


Tabel 5. Pengaruh pemberian pupuk N, K dan bakteri endofit HL.39B.86 terhadap diameter kanopi tanaman

\begin{tabular}{llrrrr}
\hline No & Perlakuan & \multicolumn{4}{c}{ Diameter kanopi tanaman (cm) } \\
& & 2 MST & 4 MST & 6 MST & 8 MST \\
\hline 1 & N0K2B1 & $39.0 \mathrm{c}$ & $73.0 \mathrm{a}$ & $61.7 \mathrm{a}-\mathrm{d}$ & $83.0 \mathrm{a}$ \\
2 & N1K2B1 & $39.7 \mathrm{c}$ & $74.0 \mathrm{a}$ & $70.3 \mathrm{abc}$ & $71.3 \mathrm{bc}$ \\
3 & N2K2B1 & $42.0 \mathrm{abc}$ & $70.3 \mathrm{a}$ & $62.0 \mathrm{~cd}$ & $66.3 \mathrm{~b}-\mathrm{e}$ \\
4 & N3K2B1 & $50.3 \mathrm{a}$ & $68.0 \mathrm{a}$ & $51.7 \mathrm{abc}$ & $54.7 \mathrm{bc}$ \\
5 & N2K0B1 & $46.7 \mathrm{abc}$ & $72.0 \mathrm{a}$ & $63.0 \mathrm{ad}$ & $66.0 \mathrm{~b}-\mathrm{e}$ \\
6 & N2K1B1 & $43.7 \mathrm{abc}$ & $65.3 \mathrm{a}$ & $66.3 \mathrm{ab}$ & $68.7 \mathrm{bcd}$ \\
7 & N2K3B1 & $44.5 \mathrm{abc}$ & $68.7 \mathrm{a}$ & $56.0 \mathrm{a}$ & $69.3 \mathrm{bcd}$ \\
8 & N2K2B2 & $49.0 \mathrm{ab}$ & $69.7 \mathrm{a}$ & $70.0 \mathrm{abc}$ & $69.7 \mathrm{bcd}$ \\
9 & N2K2S1 & $46.7 \mathrm{abc}$ & $56.7 \mathrm{~b}$ & $66.0 \mathrm{a}-\mathrm{d}$ & $54.7 \mathrm{e}$ \\
10 & N2K2S2 & $41.3 \mathrm{bc}$ & $56.3 \mathrm{~b}$ & $63.7 \mathrm{bcd}$ & $59.0 \mathrm{cde}$ \\
11 & N2K2 & $45.8 \mathrm{abc}$ & $54.7 \mathrm{~b}$ & $59.3 \mathrm{~d}$ & $57.3 \mathrm{~d}-\mathrm{e}$ \\
12 & N2K2B1 & $43.5 \mathrm{abc}$ & $66.7 \mathrm{a}$ & $71.3 \mathrm{abc}$ & $63.0 \mathrm{~b}-\mathrm{e}$ \\
13 & Kontrol & $47.7 \mathrm{abc}$ & $64.3 \mathrm{ab}$ & $70.7 \mathrm{abc}$ & $74.7 \mathrm{ab}$ \\
\hline
\end{tabular}

Tabel 6. Pengaruh pemberian pupuk N, K dan endofit HL.39B.86 terhadap jumlah buah yang dipanen, berat buah tomat dan berat biomassa tanaman.

\begin{tabular}{|c|c|c|c|c|}
\hline No & Perlakuan & $\begin{array}{l}\text { Biomas tanaman } \\
\text { Basah (gr) }\end{array}$ & $\begin{array}{l}\text { Buah (rataan/pot) } \\
\text { Jumlah }\end{array}$ & $\begin{array}{c}\text { Jumlah buah (15 x panen) } \\
\text { Berat (gr) }\end{array}$ \\
\hline 1 & $\mathrm{~N} 0 \mathrm{~K} 2 \mathrm{~B} 1+\mathrm{E}$ & 395.00 de & $8 a b c$ & 75.90 \\
\hline 2 & $\mathrm{~N} 1 \mathrm{~K} 2 \mathrm{~B} 1+\mathrm{E}$ & $482.00 \mathrm{~b}-\mathrm{e}$ & $10 a b c$ & $403.68 \mathrm{abc}$ \\
\hline 3 & $\mathrm{~N} 2 \mathrm{~K} 2 \mathrm{~B} 1+\mathrm{E}$ & $350.67 \mathrm{e}$ & $9 \mathrm{abc}$ & $250.89 \mathrm{bcd}$ \\
\hline 4 & $\mathrm{~N} 3 \mathrm{~K} 2 \mathrm{~B} 1+\mathrm{E}$ & $166.67 \mathrm{~b}-\mathrm{e}$ & $10 \mathrm{bc}$ & $352.40 \mathrm{abc}$ \\
\hline 5 & $\mathrm{~N} 2 \mathrm{~K} 0 \mathrm{~B} 1+\mathrm{E}$ & $471.00 \mathrm{~b}-\mathrm{e}$ & $5 \mathrm{bc}$ & 261. $80 \mathrm{bcd}$ \\
\hline 6 & $\mathrm{~N} 2 \mathrm{~K} 1 \mathrm{~B} 1+\mathrm{E}$ & 372.00 a-d & $11 \mathrm{abc}$ & $376.37 \mathrm{abc}$ \\
\hline 7 & $\mathrm{~N} 2 \mathrm{~K} 3 \mathrm{~B} 1+\mathrm{E}$ & $378.40 \mathrm{ab}$ & $16 \quad a$ & $574.70 \quad a$ \\
\hline 8 & $\mathrm{~N} 2 \mathrm{~K} 2 \mathrm{~B} 2+\mathrm{E}$ & $655.67 \quad \mathrm{a}$ & $9 \mathrm{abc}$ & $445.51 \mathrm{ab}$ \\
\hline 9 & $\mathrm{~N} 2 \mathrm{~K} 2 \mathrm{~S} 1+\mathrm{E}$ & $433.00 \mathrm{~b}-\mathrm{e}$ & $2 \quad c$ & $198.52 \mathrm{~cd}$ \\
\hline 10 & $\mathrm{~N} 2 \mathrm{~K} 2 \mathrm{~S} 2+\mathrm{E}$ & 422.33 cde & $7 \mathrm{abc}$ & $412.27 \mathrm{abc}$ \\
\hline 11 & $\mathrm{~N} 2 \mathrm{~K} 2+\mathrm{E}$ & $445.33 \mathrm{~b}-\mathrm{e}$ & $7 \mathrm{abc}$ & $276.92 \mathrm{bcd}$ \\
\hline 12 & $\mathrm{~N} 2 \mathrm{~K} 2 \mathrm{~B} 1+\mathrm{E}$ & $561.33 a b c$ & $9 a b c$ & $398.96 a b c$ \\
\hline 13 & N2K2 & $460.30 \mathrm{~b}-\mathrm{e}$ & $14 a b$ & $408.41 \mathrm{abc}$ \\
\hline
\end{tabular}

Pemberian pupuk nitrogen dari sumber Urea pada $160 \mathrm{~kg} \mathrm{KCl}$ dan 5 ton Pukan/ha (K2B1) secara nyata dapat meningkatkan hasil buah tomat. Bobot tomat pada perlakuan tanpa urea sebesar 75,9 gram/pot hasil tertinggi dicapai pada perlakuan $\mathrm{N} 1(67,5 \mathrm{~kg}$ $\mathrm{N} / \mathrm{ha}$ ) yaitu sebesar 403,7 g/pot.

Pemberian pupuk kalium dari sumber $\mathrm{KCl}$ pada $135 \mathrm{Kg} \mathrm{N}$ dan 5 ton Pukan (K2B1) secara nyata dapat meningkatkan hasil buah tomat. Bobot tomat pada perlakuan tanpa $\mathrm{K}$ sebesar 261 gram/pot hasil tertinggi dicapai pada perlakuan $\mathrm{K}(240 \mathrm{~kg} \mathrm{KCl} / \mathrm{ha})$ yaitu sebesar $574,7 \mathrm{~g} /$ pot. Pemberian bahan organik dari pupuk kandang tidak meningkatkan bobot tomat, demikian juga tanaman tomat memberikan efek yang sama antar sumber $\mathrm{N}$, baik urea dan ZA.

\section{$4 \quad$ Kesimpulan}

Mikroba endofit yang hidup di dalam jaringan tanaman mampu menghambat pertumbuhan mikroba patogen tanaman ( Xanthomonas campestris, Pseudomonas solanacearum, Colletotricum gloeosporioides dan Fusarium oxysporum). Ekstrak dari 
bakteri endofit terseleksi menunjukkan adanya senyawa aktif antibakteri. Perendaman biji tomat dalam kultur bakteri endofit sebelum disemai dan pemberian kultur bakteri endofit pada tanaman setelah ditanam dalam polybag, cukup efektif dapat memproteksi tanaman terhadap bakteri $P$. solanacearum, namun hal ini perlu ditunjang dengan pemberian pupuk $\mathrm{N}, \mathrm{K}$ dan pupuk organik yang tepat $(135 \mathrm{~kg} / \mathrm{ha} \mathrm{N}, 160 \mathrm{~kg} / \mathrm{ha} \mathrm{KCl}$ dan pukan 5 ton/ha).

\section{Ucapan terima kasih}

Ucapan terima kasih disampaikan kepada Pimpinan Proyek Penelitian Bioteknologi LIPI, yang telah memberikan dana dan kesempatan untuk melakukan penelitian ini. Ucapan terima kasih pula disampaikan kepada Ir. Enggis Tuherkih, Koko Kusuma, Marjuki dan Mansur (Balai Penelitian Tanah Badan Litbang Pertanian) dan kepada Nuryati (Pusat Penelitian Bioteknologi).

\section{Daftar pustaka}

Andri, C. (2004). Kajian potensi Streptomyces sp. PS1-4 sebagai penghasil senyawa bioaktif pengendali bakteri patogen tanaman kedelai Fakultas Matematika dan IImu Pengetahuan Alam, Institut Pertanian Bogor. Skripsi.

Bagchi, B., \& Banerjee. D . (2013). Diversity of fungal endophytes in Bauhinia vahlii (a lianas) from different regions of Paschim Medinipur district of West Bengal . IJSET. 2:748-756.

Bezerra, J.D.P., Lopes, D.H.G., Santos, M.G.S., Svedese ,V.M., Paiva, L.M., AlmeidaCortez , J.S., Souza-Motta, C.M.( 2012). Riqueza de micro-organismos endofíticos em espécies da família Cactaceae. Bol Soc Latin Carib Cact Suc. 9:19-23.

BPS. (2016). Statistik Indonesia. Badan Pusat Statistik.

Cacabuono, A.C., \& Pomilio. A.B. (1997). Alkaloids from endophyte infected Festua argentina. J. Ethnopharmacol $57: 1-9$.

Chandra, S. (2012). Endophytic fungi: novel sources of anticancer lead molecules. Appl Microbiol Biot. 95:47-59

Clay, K. (1986). Grass endophytes.p.190-201. In : Fokkema, N. and Van den Heuval, J., eds. Microbiology of the Phyllosphere. Cambridge University Press, cambridge, $392 \mathrm{pp}$.

Clay, K. (1988). Fungal endophytes of grasses, and a defensivevmutualism between plants and fungi. Ecology, 69:10-16.

Fabry, W., Okemo, P.O. \& Ansorg., R. (1998). Antibacterial activity of East African medicinal plants. J. Ethnopharmacol. 60 :79-84.

Hadi,S., Suseno, R., \& Sutakaria, Y. (1976). Patogen tanaman dalam tanah dan perkembangan penyakit. Dep. Hama dan Penyakit Tumbuhan. Fak. Pertanian IPB Bogor.

Hilarino, M.P.A., Silveira, F.A.O., Oki, Y., Rodrigues, L.., Santos, J.C., Junior, A.C., Fernandes, G.W., Rosa, C.A. (2011). Distribution of the endophytic fungi 
community in leaves of Bauhinia brevipes (Fabaceae) . Acta Bot Bras. 25:815821.

Hwang, J.S., You, Y.H., Bae, J.J.,.Khan, S.A, Kim, J.G., Choo, Y.S.( 2011). Effects of endophytic fungal secondary metabolites on the growth and physiological response of Carex kobomugi Ohwi. J Coastal Res. 27:544-548.)

Ifdal. (2003). Interaksi antara Streptomyces sp. dengan Bacillus subtilis, Xanthomonas Campestris pv glycine, Rhizobia dan Pseudomonas sp. Bogor: Fakultas Matematika dan IImu Pengetahuan Alam, Institut Pertanian Bogor. Skripsi.

Melliawati, R., Widyaningrum, D.N., Djohan, A.C., Sukiman, H. (2006). Pengkajian bakteri endofit penghasil senyawa bioaktif untuk proteksi tanaman. Journal of Biological Diversity. 7(3) : 221-224.

Melliawati, R., Ismawati, E., Octavina, F. (2007). Kapang Endofitik Potensial Sebagai Penghasil Anti Mikroba Patogen. Jurnal Berkala Ilmiah Biologi 6(1) :9-17.

Melliawati, R., \& Wulandari, P. S. (2008). Kapang Endofit dari Taman Nasional Gunung Halimun sebagai penghambat pertumbuhan mikroba patogen Salmonella thypi dan Candida albicans. Berkala Penelitian Hayati 13(2) : 101-107.

Melliawati, R., \& Harni. (2009). Senyawa antibakteri Escherichia coli ATCC 35218 dan Staphylococcus aureus ATCC 25923 dari kapang endofit Taman Nasional Gunung Halimun. Jurnal Natur Indonesia. 12(1) : 21-27.

Meng, L., Sun, P., Tang, H., Li, L., Draeger, S., Schulz, B., Krohn, K., Hussain, H., Zhang W., Yi, Y. (2011). Endophytic fungus Penicillium chrysogenum, a new source of hypocrellins . Biochem Syst Ecol:;39:163-165.

Muthahanas, I. (2004). Potensi Streptomyces agens pengendali biologi Raltsonia solanacearum penyebab penyakit layu tanaman cabai. Bogor: Program Pascasarjana, Institut Pertanian Bogor. Tesis

Papuangan, N. (2009). Aktivitas penghambatan senyawa antimikrob Streptomyces spp. terhadap mikrob patogen tular tanah secara in vitro dan in planta[tesis].Bogor: Program Pascasarjana, Institut Pertanian Bogor. Tesis

Pinheiro, E.A.A., Carvalh, J.M. , Santos, D.C.P. , Feitosa, A.O. , Marinho, P.S.B. , Guilhon, G.M.S.P ., Souza, A.D.L., Silva, F.M.A.,. Marinho, A.M.R. (2013). Antibacterial activity of alkaloids produced by endophytic fungus Aspergillus sp. EJC08 isolated from medical plant Bauhinia guianensis. Nat Prod Res.27:1633-1638.

Roth, L.F., \& Riker, A.J. (1943). Influence of temperature moisture and soil reaction on Damping off of red pine seedling by Pythium and Rhizoctonia. Journal of Agriculture Research 67:273-293.

Rizzo, I., Varsavky, E., Haiduhososki, M., \& Frade, H. 1997. Macrocyclic trichothecence in Barcharis coridifolia plants and endophytes and Barcharis artemisioides plants. Toxicon. 35:753-757.

Siegel, M. R., Latch, G. C. M., \& Johson, M. C. (1985). Acremonium fungal endophytes of tall fescue and perennial ryegrass : significance and control. Plants. Dis. 69:179-183.

Strobel, G. A., Hess, W. M., Ford, E. J., Sidhu, R. S., \& Yang, X. (1996). Taxol from fungal endophytes and the issue of biodiversity. J. Industr. Microbiol. 17:417-423.

Semangun, H. (1971). Penyakit penyakit tanaman pertanian di Indonesia. Yayasan Pembina Fak. Pertanian UGM Yogyakarta. 250 halaman 
Semangun, H. (1994). Penyakit-penyakit Tanaman Hortikultura di Indonesia. Yogyakarta: UGM Press. 450 halaman.

Siqueira, V.M., Souza-Motta, C., Braun, U. (2008). Corynespora subcylindrica sp. nov., a new hyphomycete species from Brazil and a discussion on the taxonomy of corynespora-like genera . Sydowia.;60:113-122.

Siqueira,V.M., Conti, R., Araújo J.M., Souza-Motta, C.M. ( 2011). Endophytic fungi from the medicinal plant Lippia sidoides Cham. and their antimicrobial activity. Symbiosis: 53:89-95.

Souza ,A.Q.L.,. Souza, A.D.L., Astolfi-Filho, S., Pinheiro, M.L.B., Sarquis, M.I.M., Pereira, J.O. (2004). Antimicrobial activity of endophytic fungi isolated from amazonian toxic plants: Palicourea longiflora (aubl.) rich and Strychnos cogens bentham . Acta Amaz:;34:185-195.

Sun, J,Q., Guo, L.D., Zang, W., Ping, W.X., Chi, D.F. (2008). Diversity and ecological distribution of endophytic fungi associated with medicinal plants. Sci China Ser C. 51:751-759.

Sutakaria, J.(1964). Penyakit penyakit pada tanaman kedelai di Indonesia. Lembaran Kerja Rapat Kerja Kedelai Bogor.

Sutakaria, J. (1975). Proteksi tanaman khususnya untuk penyakit tanaman tumbuhan. Dept. Ilmu Hama Penyakit Tumbuhan Fak. Pertanian IPB. Bogor

Suryaningsih, E., Chujoi, E., Kusmana. (1999). Identification of potato cultivars resistance to late blight through a Standard International Field Trial (SIFT) in Indonesia.In Potato Research in Indonesia. Research Result in a Series of Working Papers, 1999. Collaborative Research between The RIV and CIP. P. 37-44.

Teske, M.,\& Trentini, A.M.M. (1995). Compêndio de Fitoterapia. Herbarium Lab. Botânico; Curitiba: 317 halaman.

Wang, Y., \& Dai, C.C. (2011). Endophytes: a potential resource for biosynthesis, biotransformation, and biodegradation. Ann Microbiol.;61:207-215.

Wang, L.W., Xu, B.G., Wang, J.Y., Su, Z.Z., Lin, F.C., Zhang, C.L,. Kubicek, C.P. (2012). Bioactive metabolites from Phoma species, an endophytic fungus from the Chinese medicinal plant Arisaema erubescens. Appl Microbiol Biotechnol 93:1231-1239.

Widarto, H. T. (2008). Mendongkrak Kinerja Mikroorganisme Antagonis terhadap Patogen Tular Tanah. Direktorat Perlindungan Perkebunan. Jakarta.

Wijayani, A, \& Widodo, W. (2005). Usaha meningkatkan kualitas beberapa varietas tomat dengan sistem budidaya hidroponik. IImu Pertanian 12(1):77-83

Yang, X., Strobel G., Stierle, A., Hess, W. M., Lee, J., \& Clardy, J. (1994). A fungal endophyte-tree reletionship : Phoma sp. In Taxus wallachiana. Plants Sci.102:1-9.

Yusniawati, R,.D. (2009). Potensi Streptomyces spp. sebagai penghambat cendawan tular tanah Sclerotium rolfsii secara in vitro dan in planta pada tanaman tomat (Solanum lycopersicum) Bogor: Fakultas Matematika dan Ilmu Pengetahuan Alam, Institut Pertanian Bogor. Skripsi. 